\title{
Science, governance, and public participation: An analysis of decision making on genetic modification in Aotearoa/New Zealand
}

\author{
By Priya Kurian \& Jeanette Wright \\ Political Science and Public Policy \\ School of Social Sciences \\ The University of Waikato \\ Hamilton 3240, New Zealand \\ Email: pkurian@waikato.ac.nz; imw6@waikato.ac.nz \\ Corresponding Author: Priya Kurian
}

\author{
Published online 29 September 2010 Public Understanding of Science \\ DOI: 10.1177/0963662510382362 \\ The online version of this article can be found at: \\ http://pus.sagepub.com/content/early/2010/09/24/0963662510382362
}

\begin{abstract}
The acceptance of public participation in science and technology governance in liberal democratic contexts is evident in the institutionalization of a variety of mechanisms for participation in recent decades. Yet questions remain about the extent to which institutions have actually transformed their policy practice to embrace democratic governance of techno-scientific decision making. A critical discourse analysis of the response to public participation by the Environmental Risk Management Authority (ERMA), the key decision-making body on genetic modification in Aotearoa/New Zealand, in a specific case demonstrates that ERMA systematically marginalized concerns raised by the public about risk management, ethics, and ecological, economic, and cultural issues in order to give primacy to a positivist, technological worldview. Such delegitimization of public perspectives pre-empts the possibility of the democratic governance of science.
\end{abstract}

\section{Keywords}

Decision making on genetic modification, governance of science and technology, policy practice, public participation 


\section{Introduction}

In the last two decades, governments have increasingly acknowledged the need for public participation in science and technology, given growing public disenchantment with science and scientists in the wake of accidents such as those at Bhopal and Chernobyl, and crises such as over BSE/mad cow disease, exposure to dioxin, nuclear radiation, $\mathrm{PCBs}$ and other chemicals. In Europe, multiple forms of public participation have been institutionalized in the form of citizen juries, consensus conferences, and other types of public deliberations on contentious issues such as genetic modification and nanotechnology (Baber and Bartlett, 2005; Kleinman et al., 2009; Murphy et al., forthcoming). Indeed, some scholars argue that public participation has acquired hegemonic status in science governance today, with broad acceptance of the vocabulary of "'public participation,' 'dialogue', or 'public engagement'" by liberal democratic states (Braun and Schultz, 2009: 1).

Despite the proliferation of participatory mechanisms, it is critical to recognize that "formal participatory opportunities cannot by themselves ensure the representative and democratic governance of science" (Jasanoff, 2003: 237). Too often, they run the risk of being (or of being perceived as) merely symbolic exercises in legitimation (Goven, 2006). A key question, therefore, is the extent to which regulatory institutions of the state, facing competing pressures from a range of publics, are able to fulfill their obligations for democratic governance. How well do such institutions emulate the political practice of "expansive democracy" (Warren, 1992) by becoming responsive to a vocal and diverse range of publics?

The need to institutionalize some form of public participation-whether to regain the legitimacy of public institutions, curb public unrest, or make better substantive decisions-has taken on greater urgency in the context of the "radical uncertainty" (Hajer and Wagenaar, 2003: 9) of modern "risk society" (Beck, 1992). Governments as much as publics are aware that decisions on technoscientific developments can no longer be made by policymaking institutions governed by a "technocratic ideology" (Fischer, 1995: 175). Hajer and Wagenaar (2003: 10) argue that it is precisely a recognition of the limits of knowledge which has led to acceptance of concepts such as the precautionary principle, whereby "we institutionally aim to avoid risks knowing that science might, ultimately, show the inconceivable ... to be true." Notwithstanding acceptance of such concepts in policy and legislation, the question remains whether institutions have actually transformed policy practice and opened up the content of policy decisions to public input: is there evidence to demonstrate that public participation in science governance is more than merely symbolic?

In order to examine whether participation has had a substantive impact on policy decisions, we analyze institutionalized public participation in decision making around genetic modification, a contentious and divisive policy issue in Aotearoa/New Zealand. We explore the practice of public participation through a case study of the Environmental Risk Management Authority (ERMA) of Aotearoa/New Zealand, the key institution in the decision-making process around genetic modification. In Aotearoa/New Zealand, all applications for release, or use in field trials, of genetically 
modified organisms (GMOs) must be submitted to ERMA for approval; those deemed to invoke significant public interest are required to hold public hearings. In addition, the Hazardous Substances and New Organisms Act (HSNO) 1996, which created ERMA, emphasizes the importance of public participation and indigenous views in all decision making, even while giving operational primacy to scientific risk management of GMOs (Wright and Kurian, 2009). There appears to be an overt legislative commitment to inclusive decision making as part of science governance likely to allow for meaningful public participation. Whether this is so in practice is the focus of this article.

We explore how ERMA deals with the range of public discourses on GM through an analysis of an application in 2002 by AgResearch Ruakura, a publicly funded research institution, to insert human genes into cattle, the resulting 863 public submissions, and the evaluation report and final decision from ERMA. We examine how decision-making processes respond to public voices, including those of Maori, environmentalists, scientists and bio-ethicists. How are citizen participants constructed by policy processes? Whose realities and knowledges are deemed legitimate? How do institutions "respond to the multiple voices of the citizens they are meant to serve?" (Gaventa, 2005: vii). To what extent do worldviews of participants in the decision making process reflect tendencies towards 'Promethean' or 'precautionary' perspectives (Dryzek et al., 2009) $?^{1}$ Ultimately, we reflect on implications of this case for our understandings of public participation and institutional practice in the democratic governance of science and technology.

The article thus contributes to a growing scholarship on constructivist dimensions of public participation in science governance and on notions of policy practice (Wagenaar and Cook, 2003; Hajer, 1995). A brief review of these concepts follows before we turn to specifics of the case.

\section{Public participation and policy practice}

Dynamics and tensions inherent to public participation in decision making on the use of technologies, as well as in the influence of science on policy and governance, and clashing perspectives of policy elites and lay publics have been explored in considerable depth by scholars in science and technology studies (see, e.g., Jasanoff, 1990, 2003, 2005; Wynne, 2001; Irwin, 2001; Irwin and Michael, 2003; Pestre, 2008; Dryzek et al., 2009; Braun and Schultz, 2009; Murphy et al., forthcoming). These works explore the contentious nature of democratic governance of science, their central concern how best to ensure the accountability of science and industry to "fundamental questions of democratic politics.... Who is making the scientific and technological choices that govern life? On whose behalf? According to whose definitions of the good?" (Jasanoff, 2005: 190).

These questions on democratic accountability are particularly significant in a global context where major economic actors constitute "a meta-power" that can too often bypass states or demands of the public sphere (Pestre, 2008: 105). Tensions between the public/political and the economic is perhaps most evident in the area of "regulatory science," which is bound by institutional context and political pressures, and 
driven by agendas of both government and industry (Jasanoff, 1990). Thus, even as discourses of participation become entrenched in a new form of governmentality, democratic political control is rarely exercised over decisions on the manufacture and distribution of techno-scientific products such as genetically modified organisms and foods (Pestre, 2008).

Public scepticism or hostility towards GMOs, evident in people's input into regulatory decisions on GM products, tend to get typecast as concerned primarily with "subjective ethics" as opposed to "objective risks" that scientific experts could comment on (Wynne, 2001; Levidow et al., 2005). Thus, in the case of agricultural biotechnology in Europe, Ferretti (2007) demonstrates how public input into decision making processes was rejected as irrelevant to technical criteria established by the regulatory framework. Similarly, Dryzek et al. (2009) found that policy elites consistently demonstrated a "Promethean" worldview in contrast to the "precautionary worldview" of mini-publics. Clearly, public participation in science governance does not automatically inform policy.

Scholarship on public participation also reveals the significance of policy practice. According to Wagenaar and Cook (2003: 149), policy practice entails "action, community, situatedness, criteria, standards, warrants, knowing, dialectic, discourse, emotions and values." To understand whether and in what ways public participation informs science governance, we need to examine these elements of specific policymaking practices of institutions. Do institutional practices for public participation allow for "the articulation of conflict and difference, as a place of social and cultural contestation" (Hajer, 2003: 99)? For Hajer (1995, 2003), analysis of deliberative policy practice is best undertaken through discourse analysis that allows study of "terms of policy discourse,... formation of alternative discourse coalitions,... and the particular institutional practices in which discursive conflicts are played out" (2003: 102). We discuss the discourse analysis used in the case study later in this article, turning now to the issue of genetic modification and its governance in Aotearoa/New Zealand.

\section{The context}

Genetic modification in Aotearoa/New Zealand is regulated by the Hazardous Substances and New Organisms Act (HSNO) of 1996. The 'principles' and 'purpose' of the HSNO Act acknowledge the importance of ecological sustainability, public participation, inclusion of different cultural ethics, indigenous views, and ecological science. The Act also specifies that an application to create GMOs can only be rejected if scientific analysis reveals potential risks of the organism as too high (HSNO Act 1996, Part V, 29).

The Act led to the creation of ERMA, which comprises a quasi-judicial body, the Authority; a committee to advise the Authority on Maori issues, Ngā Kaihautū Tikanga Taiao (NKTT); and the operational body, the Agency. Members of the Authority and NKTT are appointed by the Minister for the Environment. As directed by the Act, ERMA developed a Methodology Order, which has the status of "delegated legislation" (ERMA, 1998: 3), to evaluate all applications. The Methodology Order emphasizes that ERMA's 
decision making must be led by an "objective" and "scientific" analysis of costs, benefits and risks associated with new organisms and hazardous substances, while acknowledging the general principles and purpose of the Act (ERMA, 1998). Thus, contradictions within the HSNO Act are reflected in the Methodology Order (Wright and Kurian, 2009).

Although GM experimentation has existed in Aotearoa/New Zealand at least since the 1970s, it was only in the 1990s that public anxiety and environmental concerns about the issue came to the fore. Spilling over into massive protest demonstrations against its use, it led to the setting up of the Royal Commission on Genetic Modification (RCGM) in 2000 to enquire into the role of GM in Aotearoa/New Zealand. Following the RCGM's (2001) recommendation that Aotearoa/New Zealand should "proceed with caution," the government in 2003 lifted a moratorium on the commercial release of GMOs, while continuing to allow contained GM experimentation on plants and animals (Kurian and Munshi, 2006). A new application by AgResearch to insert human genes into goats, sheep and cows, currently being considered by ERMA, has attracted 1545 written public submissions, over 90 percent of which oppose the proposal (New Zealand Herald, 27 February 2010). Thus, GM continues to have significant public salience in Aotearoa/New Zealand.

GM has also attracted scholarly interest, the work of the RCGM (2001) receiving critical attention in particular (see, e.g., Goven, 2006; Rogers-Hayden, 2004). Where public participation is concerned, ERMA invites the public to make submissions on publicly notified applications and be heard in public hearings, resulting in a consultative process wherein the Authority determines what credence should be given to public input (Wright and Kurian, 2009). ERMA is also required by the Act and the Methodology Order to develop mechanisms and processes "to take account of" the Maori worldview.

Analysis of practices that structure public participation will allow us to address the key question of whether and in what ways diverse citizen perspectives on biotechnological developments are given legitimacy by ERMA. This is particularly important in light of recent research that argues ERMA's decisions are likely to "support those views reflecting strong scientific and economic discourses, while simultaneously rejecting views that encompass issues of cultural and social values, ethics, power, inequality and inequity" (Wright and Kurian, 2009).

This article explores ERMA's responses to public participation in the face of contradictions between the principles and purpose of the HSNO Act 1996, on one hand, emphasizing public participation, ethics, and ecological sustainability, and the primacy given by the Act and the Methodology Order to scientific expertise, on the other.

\section{Methodology}

For the case study, we use critical discourse analysis (CDA) which focuses on the political and ideological significance of words. Following Fairclough (1995), we examine discourses of power that underpin relevant texts, especially because discursive practices within institutions, embodied in norms, rules and routines of political institutions, frame the context of political practice (March and Olsen, 1989). 
Discourse is "a specific ensemble of ideas, concepts, and categorizations that are produced, reproduced, and transformed in a particular set of practices and through which meaning is given to physical and social realities" (Hajer, 1995: 44). Discourse analysis involves analysis of storylines, myths, metaphors, and of policy vocabularies comprising concepts developed by policy makers structuring particular policies (Hajer, 2003: 104). It makes evident the coalition of those actors who support or oppose particular policies and shows how discourse is structured and conflicts are played out in institutionalized practice.

For the case study, we gathered the AgResearch application (AgResearch, 2002), all submissions made to ERMA, the ERMA evaluation and review (E \& R) report (ERMA 2002a), and the ERMA decision (ERMA, 2002b). We read and re-read all documents to identify specific arguments, concerns and worldviews of different actors. In the analysis that follows, quotes from submissions are identified by name of author followed by submission number as recorded by ERMA. Supporting the application were four organizations - the Life Sciences Network (LSN), representing "industry, universities, research and producer organisations and investors in biotechnology and genetic modification" (LSN, 4136:1); Fonterra, representing 13,000 dairy farmers in Aotearoa/New Zealand; Federated Farmers, a farming sector lobby group; and the New Zealand Organisation for Rare Disorders (NZORD) - and five individuals. These echo to a large degree views put forward by AgResearch in its application, and hence are discussed together with the application. In opposition were environmental organizations and activists, the Green Party, Maori organizations, and hundreds of members of the lay public. The oppositional perspectives and ERMA's responses to the various arguments are discussed in a separate section.

The significance of this work is that, with few exceptions a critical discourse analytic approach has not been the centre of scholarship analyzing public participation and decision making on GM. This article is also the first to systematically analyse AgResearch's application in 2002 to insert human genes into cattle. Thus it offers both an analysis of ERMA's response to public participation and a benchmark for future analysis of ERMA's practice.

\section{The case study: AgResearch Ruakura application GMD02028}

In 2002, AgResearch applied to ERMA for approval to develop transgenic cattle that could produce human proteins in milk and to study gene function and genetic performance, with an overarching purpose of meeting "human health clinical needs" (AgResearch, 2002: 9). As part of the application process, AgResearch was required to identify and assess the effects of its proposed experiment on the transgenic animals, the environment and ecosystems, public health and Maori; and the quantified risks and costs and benefits of the experiment (HSNO Act 1996, Section 40). The AgResearch application identified no adverse negative effects on flora and fauna and no ethical issues regarding the use of animals (AgResearch, 2002: 2-3). Similarly no adverse effects on human health or safety were anticipated, as the transgenic cattle would not enter the food chain because of the "comprehensive containment facility and regime" in the 
form of fencing paddocks where the cattle would be kept (AgResearch, 2002: 33), as required by its risk management procedures.

Evaluating the risks of the experiment, it acknowledged there were possible risks from "inadvertent cloning of human virus receptors possibly providing a new reservoir for human viruses," possible horizontal gene transfer (HGT), new allergens, and problems with antibiotic resistance (AgResearch, 2002: 38). But AgResearch (2002) argued that the probability and magnitude of these arising were very low and rejected the possibility of any long term unanticipated risks.

The only significant risks in its view were the affront to spiritual beliefs and values of Maori and others, which "may be of a high magnitude" and could have "health implications for those with these beliefs" (AgResearch, 2002: 36), but which, it argued, should not stop the experiment. Finally, its analysis suggested that any costs would be offset by the expected benefits of its experiment, such as retention of intellectual capital.

The Life Sciences Network, Fonterra, Federated Farmers, NZORD, and five individuals made submissions that aligned with Agrearch's application. They focused on the benefit of scientific discoveries for human and animal health, the resulting impetus to economic growth, and progress of the bioscience industry in Aotearoa/New Zealand. These supporters argued that Maori objections to GM experiments should not be allowed to obstruct approval of the application, especially as AgResearch had met its legal obligation of consulting Maori groups.

AgResearch, in its classification of risks, costs and benefits, constructed a storyline in which scientific and economic benefits were validated, whilst non-monetary cultural and ethical values were seen as 'conjectural', 'unproveable' and hence of little account. There is little room here for more complex ecological considerations. In its faith in the value of human manipulation of nature, desire for commercial gains, and rejection of any precaution with regard to risks from GM experimentation, the application appears to embody the "Promethean worldview" (Dryzek et al., 2009). Both the application and those supporting it viewed public participation as a legal requirement that would allow a range of views to be recorded but with no obligation to accept or engage with those opposing the application. This application also saw the formation of a discourse coalition of a publicly funded research institution and powerful actors from science and industry to further the cause of GM experimentation.

\section{Oppositional voices and ERMA response}

The application by AgResearch provoked significant public response, with 863 submissions received by ERMA; over 95 percent opposed the proposed experiments. These submissions offered views on a range of concerns including legal, scientific, environmental, ethical and cultural issues. For example, the legal focus of the submissions was both on specific legal interpretations pertaining to how the application undermined the statutory intent of the HSNO Act (for example, Bleakley, 3541; Green Party, 3542), and more general legal risk concerns: inadequacies of the application with regard to broader legislative requirements such as the Treaty of Waitangi ${ }^{2}$ (Generic ${ }^{3}$; 
Webster, 3712; Ngai Tahu, 3424; Nga Kaihautu Tikanga Taiao [NKTT]); the Animal Welfare Act (Bleakley, 3541; SAFE, 3464); the Crown Research Institute Act 1992 (Webster, 3712); the New Zealand Bill of Rights Act 1990 (MAdGE, 3591); and international treaties such as the Bio-safety Protocol and Cartegena Protocol (Groundswell, 3717).

In addition, economic risk arguments drew attention to how the experiment would affect the burgeoning organics industry, the current agricultural and tourism industries, with the loss of the 'clean, green' image (Bio-grow, 3497; Generic). Concern was also expressed that AgResearch had no liability if it caused economic and environmental harms (Generic). For others, the concern was that this type of experiment undermined teachings of the Bible and lessons from evolution (Mitchell, 3523; Steyn, 3771).

This list of concerns suggests that this heterogeneous group shifted and broadened the boundaries for risk considerations in relation to GM organisms. Although many submissions engaged with technological risks of this experiment, these risks were presented in conjunction with a risk analysis that incorporated overlapping cultural, ethical and ecological arguments. The meaning of risk was thus redefined with the expectation that such non-quantifiable values would be given due consideration by ERMA in its decision-making.

ERMA's response to the application and submitters is encapsulated in two documents: the E \& R Report (ERMA, 2002a) and the Authority's decision on the application (ERMA, 2002b). In the discussion that follows, we focus on some key narratives, emerging from a close reading of all submissions, which encapsulate the core concerns of the submissions and ERMA's response to each of these: (1) legal and risk management discourses ${ }^{4} ;(2)$ the contested science of $\mathrm{GM}$; $(3)$ ethical concerns with regard to animal welfare; and (4) the Maori worldview as it intersected with AgResearch's application.

\section{Legal and risk management discourses}

One set of opposition to the AgResearch application focused on seeming legal anomalies, several submissions arguing that the application was in violation of the statutory intent of the HSNO Act, and requirements of the ERMA Methodology (1998). The Green Party, for example, argued that:

The application is not precise enough to meet requirements of S.40 (2)(a)(iii) of the Act. ... The Applicant seeks approval on a project rather than a single organism basis ... this was not the basis on which ERMA intended to assess applications. (Green Party, 3542).

Furthermore, from a risk management perspective, the Green Party firstly argued that approval of the application would allow AgResearch to not have to reapply for any future genetic modification on cattle. Secondly, if approval was given before the appropriateness of such experiments were considered by a Bioethics Council ${ }^{5}$, all future cases involving mammalian (including human) genes would be outside the Bioethics 
Council's influence because AgResearch would not be required to come back to ERMA for approval (ibid.).

Another major concern of the submitters was whether AgResearch was correct in labelling the experiment as a "development", understood by the HSNO Act to mean the genetic modification of an organism in containment (HSNO Act, 1996). Critics said that the application should rather be understood as a "field test," defined by the Act as involving testing of GMOs already developed. As it was possible for transgenic microorganisms to escape-even if the GM cows remained confined in their paddocks-the submitters argued that it was effectively a field trial. Challenges posed by the submitters focused on both violation of the legal intent of HSNO and consequent risks faced by society.

There was concern that it would be impossible to contain genetic material from the experiment and that "the effects of a transgene construct that has never existed before" were "incalculable" (Friends of the Earth, 3836). Submissions also made extensive use of the notions of 'precaution' and the 'Precautionary Principle', as the following submission reveals: "The acceptability of scientific uncertainty diminishes when the severity of potential negative effects increases. The precautionary approach should be upheld" (GE Free NZ, 3497). Risk management itself is seen in this narrative not as something to be undertaken through a quantitative risk-benefit analysis, but rather within a broader, more contextual understanding of risk.

\section{ERMA response to legal and risk management issues}

Although ERMA acknowledged that "on a strict interpretation of the requirements AgResearch had possibly failed to identify all possible adverse effects" (ERMA, 2002b: 12 ) and that the information given was "barely adequate" (ERMA, 2002b: 12), it stated that the legal requirements were sufficiently met for the application to be considered. On the question of "development" versus "field test", the Authority deemed that although the application met the requirements of a "development", it did involve elements of field testing, such as testing effects of GMOs through milking the transgenic cows.

The Authority therefore set restrictions on the scope of the approved organisms, adding more controls to reduce uncertainty. The extension of controls required the applicant to monitor for horizontal gene transfer at the disposal sites (if detected the project would be suspended), bury all cows within the containment site (including surrogate cows) and spray or burn milk products within the containment site (ERMA, 2002b: 25).

The Authority argued that the requirement in the HSNO Act for information on all possible adverse effects of the organism on the environment "set a high standard." The Application's lack of specificity in its description of the organisms, and the fact that the organisms were to be outside rather than in a contained laboratory meant that the applicant "had possibly failed" in this regard (ERMA, 2002b: 12; emphasis added). However, it stated that: 
A standard of reasonableness should be applied when assessing the extent to which identification of adverse effects was required. ... On balance the application could be regarded as valid (ibid.).

Clearly, ERMA's focus was on satisfying legal requirements instead of ascertaining environmental risks.

The Authority's approach in this decision undermined the precautionary approach and appears contradictory to the intent of the HSNO Act. It did not require AgResearch to establish the safety of the experiment, and it relied on legal rationality as a justification for approval, which it deemed a valid approach to risk management for GMOs.

In summary, the Authority's decision to introduce more controls and restrictions was balanced by its decision to approve the application. Whilst restrictions and controls reduced the scope of the application and addressed a few of the key concerns of opposing submitters, it is clear that AgResearch's application provided insufficient information to identify risks and was by ERMA's own methodological standards inadequate for risk management of GMOs. Evident here is a strong orientation towards supporting science, technology, and enterprise over a more ecological and precautionary perspective. Its response to the legal and risk management issues raised by the submissions indicates a bias towards select technical expertise alongside a reluctance to give credence to other forms of expert knowledge.

Contested science: Meanings of the gene

Many opponents of the application challenged the science of molecular biology. Two overlapping narratives dominated these submitters' critique of AgResearch's application. The first was a scientific challenge to the notion that genes are stable entities with clear structures and function. The second drew on a social constructivist view to challenge the hegemony of the epistemological framework of positivist methodology as being the only way of knowing the world. Both narratives place context at the heart of their concerns, the context of the gene and sociocultural context.

Scientific criticism of the AgResearch application is based on a view that emphasized the importance of context in understanding how genes function in relation to other genes. For example, Dr Peter Wills, a theoretical biologist, suggested that the proposed risk management of the transgenic cows in a field was inadequate because it was not possible to compare the risks of an animal with the risks of a gene:

Genes produce risks as a result of the cellular environment in which they are placed, and when they are transposed from one environment to another, there are new risks that arise from the novel interactions between the proteins that evolution has not placed together (Wills,3899).

The uncertainty of GM science was also highlighted by Greenpeace (4132), who stated: "GM constructs may unwittingly allow pathogens access to the DNA of higher plants and animals resulting in the development of novel pathogens." Others, such as 
microbiologist Dr Neil McGregor (3533), focused on the limited state of knowledge on the possible impacts of GMOs on soil, agriculture, and forestry. These submissions challenge the scientific expertise of AgResearch and highlight the limited scientific knowledge on environmental impacts of GMOs.

These examples from submitters opposing the application reveal a critical focus on the contingency of scientific facts (Wynne, 2001), which raises questions about the risks posed by AgResearch's proposed experiment. Linked strongly to the science critique was a challenge to the dominant mechanistic worldview. For these submitters, the risk of manipulating a gene is more than the sum of its particular traits, and they articulated a strong ecological rationality (Bartlett, 1986), marked by a presumption of interdependence (everything is connected to everything else). At the same time, it is noteworthy that these opposing views on GM science are reflective of a conflict that, as Jasanoff (2005: 187) argues, is "played out on the cognitive high ground of the reliability, or not, of truth claims about a science-based technology. It is not ...a debate about what forms of life, both biological and social, should be produced by means of genetic engineering, nor about how ... its uses [be] directed by the global publics for whom its products are allegedly intended."

\section{ERMA response to scientific challenges}

The two ERMA texts only minimally explored the contested nature of the science of GM. While there was some amelioration of scientific risk concerns of those opposing the application in its decision, ERMA cited published scientific research to dismiss the scientific premises of some of the arguments that challenged GM science.

It also drew on mainstream risk assessment strategies to assess the probability of identified risks as low and the magnitude of the effects as minimal (ERMA, 2002a: 43). For ERMA, it was low risk because:

The experiment was local, site specific, and only involved a small number of cows, and even though there may be high magnitude adverse effects, because these will be mainly on the animal, they therefore have minimal effects on the environment or human health (ERMA, 2002b: 30).

This proclivity of the institution overseeing GM to engage seriously with only certain technical dimensions of scientific risk as it could occur at AgResearch meant that alternative scientific views were marginalized. Indeed, an independent review of ERMA noted the "discomfort" of ERMA staff with aspects of any application that fall outside the technical sciences: "Rooted strongly in scientific disciplines, staff are inclined to accept data where it is available and regard non-scientific, especially non-quantified aspects as less significant" (ERMA, 2003: 49).

While the precautionary principle would acknowledge limitations of science in predicting impacts, and would encourage broader social and scientific input into decisions (Mayer et al., 1996), ERMA staff seemed unable to "draw information and wisdom from orthodox as well as unorthodox expertise" (van Dommelen, 1999: 20). There was no place within their methodology to acknowledge the debate within the field of molecular biology. Thus, ERMA's "Promethean worldview," marked by strong 
techno-optimism, allowed discursive practices that served to control the debate on the AgResearch application.

\section{Animal welfare and ethics}

Issues of animal welfare and ethics formed a major theme of many submissions opposing the AgResearch application. These submissions drew on notions of consequentialist ethics and deontological ethics. Consequential ethics, in the context of animal welfare, is framed around a threshold of pain and suffering for the animals, exceeding which an experiment should not proceed. Deontological ethics, in contrast, suggests that some actions should not be performed irrespective of the consequences and that it is ethically wrong to violate the species-specific nature of animals, the most important indicator of intrinsic value. From this deontological view, production of transgenic animals by crossing the species barrier violates the nature or integrity of the animal even if there is no indication of suffering.

Submissions presented by Claire Bleakley ${ }^{6}$, Physicians \& Scientists for Responsible Genetics (PSRG), and the Generic public focused attention on pain and suffering caused by GM experiments. For example, Bleakley's submission stated:

The annual report to ERMA NZ (from AgResearch Ruakura) for GMF000023, 000024,000026 , show every casein plus calf has immune deficiencies. Out of 60 embryos ... 8 calves came to term, 2 calves died at term. Analysis showed they were severely deformed; no urinary tract, or digestive system, lungs did not inflate (Bleakly, 3541).

These submitters did not overtly object to the validity of such experiments, but focused on whether the ensuing suffering in animals contravened current legal parameters.

By contrast the next group of submitters introduced deontological ethical arguments, presenting a broader definition of animal welfare, and called for the experiments to be stopped. These submitters were critical of the anthropocentric and utilitarian use of animals by AgResearch, and emphasized the need to extend moral rights to these animals, reflective of an ecocentric discourse (Eckersley, 1992). An example of this is seen in the submission by Save Animals from Exploitation (SAFE):

Intrinsic worth is rooted in the integrity of the animal genome; animals are more than a set of physical traits or capacities. They require dignity. Dignity is related to the wholeness of the living being ... respect for dignity then equals respect for the entire being as a symbol of its evolutionary history...(SAFE, 3464).

Moral, spiritual and rights-based ethical approaches were also evident in many statements of other submitters:

Animals are sacred ...but this kind of experiment reduces them to a machine, it is not acceptable and not ethical (Alabaster, 3593). 
We should not assume a right to use animals in a way which violates fundamental natural boundaries (Harrison, 3936).

Although both deontological and consequential arguments were presented, animal welfare was the primary concern in all submissions. Most submitters also argued that no decision should be made on the application until the Bioethics Council had started functioning.

In sum, whilst the AgResearch application argues that its institutional ethics committee's oversight of animal welfare is sufficient, these submissions, by introducing narratives concerned with animal integrity and intrinsic worth, challenge the mechanistic animal welfare discourse presented by AgResearch, providing different criteria for judging right and wrong.

ERMA response to animal welfare issues

The E \& R report and the Authority's decision failed to engage with the deontological and consequentialist ethical arguments with regard to unnecessary pain and suffering of animals presented by the public. There is no legislative mandate to deal with animal welfare issues under the HSNO Act other than in terms of "the magnitude of the outcomes" arising from genetic modifications of animals (ERMA, 1998, clause 12). But, as actual outcomes were not specified in the application and hence were uncertain, and given the oversight of the Ruakura animal ethics committee (RAEC), the Authority concluded that animal welfare risks were low. The $E \& R$ report stated that:

The HSNO Act is not the legislative framework for evaluation of animal welfare issues. Therefore even though animal welfare was a major issue in submissions we do not discuss these issues in this report (ERMA, 2002a: 23).

And the Authority's decision stated that:

Whilst there may be adverse effects on animal welfare and the significance of these effects is subject to considerable uncertainty, ... the magnitude ... will range from minimal ... to moderate (in a range from no observable adverse effects to morphological, physiological, or behavioural abnormalities or in severe cases premature death of animals). Such adverse effects are considered to be local in that they affect only the animal itself (ERMA, 2002b: 29-30).

ERMA's response to concerns about animal welfare risks strongly suggests a utilitarian worldview. In the conclusion of their Decision, they stated that even though for some submitters animal ethical issues were "non-negligible," and there was "a high level of public concern over the appropriateness of GM as a technology, and the modification of food-producing animals in particular," they did not consider "that such ethical concerns are overriding" (ERMA, 2002b: 47). The Decision thus enabled ERMA to elide the more complex ethical questions presented by the submitters. 
Maori as tangata whenua (indigenous people of Aotearoa/New Zealand) signed the Treaty of Waitangi with the British Crown in 1840, giving them legal and statutory rights. Article II of the Treaty guaranteed Tino Rangatiratanga or sovereignty, namely the right of Maori to possess and control that which is theirs in accordance with their own cultural preferences (Henare, 1998).

In 1975 the Treaty of Waitangi Act was passed, which introduced key principles inserted as Treaty of Waitangi clauses into legislation. The HSNO Act (1996) under S5(b), S6(d) and S8 is informed by this statutory duty to consider Treaty obligations to Maori with regard to new organisms. This means ERMA must "take into account" the "Maori worldview" in decision making (HSNO Act 1996). It is broadly acknowledged that the Maori worldview, although not homogeneous, sees biophysical and spiritual concerns as intertwined and both dimensions must be considered (Roberts et al., 2004). The concepts of Whakapapa (genealogy) and Mauri (life force) are key to Maori understandings of the world. From this view, mixing of the Mauri (life force) of species is abhorrent and interferes with Whakapapa. Interference with Whakapapa and Mauri is seen as culturally and spiritually dangerous. This has seen persistent opposition to GMO experiments even if biophysical risks are deemed low.

Maori opposition to the AgResearch application came from Nga Kaihautu Tikanga Taiao (NKTT), Ngai Tahu and Dianne Webster. Ngati Wairere as manawhenua (the local sub-tribe) was consulted by AgResearch, and agreed to support the application if attention to new biophysical controls (burying of GM animals in lined offal holes to stop leakage) were adhered to by AgResearch. The consultation documents showed that even though Ngati Wairere accepted the compromise of changing burial procedures, the spiritual and cultural affront of this experiment remained unaddressed by $\mathrm{AgResearch}$ and was of ongoing concern to them.

The Ngai Tahu submission focused on cultural and spiritual concerns and their inability to separate these from environmental concerns. They state that in their worldview:

All species have their own Mauri, which must stay with their own species. In our culture, we as human beings are seen as in no way superior to other living things. We make use of other species in the natural world and they make use of us when we die. [The] mixing of the life force of one species with another by human beings is not tika [correct] and will adversely affect all of us (3424).

Other submissions focused more specifically on the political and legal intersections of the application and how the application and current ERMA approach failed to honour Treaty of Waitangi obligations and the HSNO Act, which had allowed again for the "de-legitimisation of the Maori worldview" (Webster, 3712).

The NKTT report to the ERMA Authority highlighted four key concerns. First, they argued that section 6(d) of the HSNO Act required AgResearch to consult all Maori, not 
merely Ngati Wairere, as issues of Whakapapa and Mauri were of concern to them all. NKTT also challenged Ngati Wairere's compromise position to accept the proposal by AgResearch to deposit dead material from the transgenic cows into lined offal holes. In NKTT's view, this was "culturally inconsistent" and went against the relationship of Maori with Papatuanuku (Earth Mother) in that these remains will be "uncleansed by Papatuanuku" (NKTT, 2002: 3). Other concerns viewed as being in violation of the HSNO Act (ibid.: 6) were the absence of any reference to the Treaty of Waitangi and "the intellectual vacuum with regard to Tikanga Maori".

In summary, for Maori this application to produce GM cattle was culturally offensive and trampled on their values. Spiritual, cultural and ethical objections they offered reflect an ecological worldview that rejects boundaries between humans and nature. At a more fundamental level, what we see here is not just an epistemic conflict between scientific and indigenous ways of knowing, but "reflections of different ways of being, of practising and relating-of ontologies" (Leach, Scoones, and Wynne, 2005: 5).

\section{ERMA response to Maori concerns}

ERMA's response acknowledged that Maori have their own framework of thinking that it was required by the Act to take into account in making a decision. ERMA dedicated over four pages of the Decision to exploring the spiritual and ethical concerns raised by Maori (ERMA, 2002b: 31-36), while a further three pages discussed the relevance of the Treaty of Waitangi to the application (ibid.: 36-38). These discussions reveal ERMA's struggle to respond to imperatives of Maori spiritual and ethical challenges in the face of seemingly more tangible scientific risk analysis studies provided by the applicant.

The E \& R report stated that the applicant had fulfilled all legal requirements of consulting with the local hapu (sub-tribe) Ngati Wairere as extensively as could be "reasonably expected" (ERMA, 2002a: 44). The Authority reiterated this view stating that consultation had been sufficient for the purposes of Section 8 of the Act (ERMA, 2002b: 36). The E \& R report also advised the Authority to follow the legal precedent set by a previous decision, in which the Authority had stated that Maori spiritual beliefs could not outweigh the scientific benefits of research (ERMA, 2002a). The Authority concurred, deciding that active protection of Maori spiritual beliefs did not "extend to accepting those beliefs as the determinant of whether the research proposed by the applicant should be approved" (ERMA, 2002b:38). It would be "unreasonable" to let Maori beliefs prevail "over all other considerations" (ERMA, 2002b: 37-38).

ERMA also decided that it would be better to bury the cows in unlined offal holes. While this approach supported the NKTT view of the "cultural inconsistency" of burying the cows in lined offal holes, it undermined the consultation agreement reached between AgResearch and Ngati Wairere.

Furthermore, in its Decision, the Authority offered "a line of reasoning on the spiritual and ethical considerations" for Maori (ERMA, 2002b: 33):

The mauri of a human is to be a human-this is its nature. The mauri of a gene is to be a gene and produce a protein - this is how the gene expresses its nature.... When the genetic material is extracted, it only has its own mauri, which is not 
the mauri of the human from which it derives because the totality of the human is not present in the individual gene. It thus follows that the gene does not introduce the mauri of the human into the cow (ERMA 2002, 34).

We see here an attempt to incorporate the meaning of key Maori cultural concepts into a modernist technical framework unable to give credence to the holistic approach of the Maori worldview. The response exemplifies the seeming inability of institutions such as ERMA to incorporate a broad range of social, cultural and ethical perspectives as the preferred approach to deal with complex social and environmental issues.

In summary, ERMA could quantify and make a risk, cost, and benefit assessment of the tangible elements of this experiment on Maori (which it did and found that there would be no significant adverse effects), but there was no means within this framework to evaluate what it saw as "the purely spiritual belief based elements of risk" (ERMA, 2002a: 50). Whilst Maori are acknowledged as having their own framework of thinking, ERMA struggled to fulfil its legal obligation to take account of Maori values. The Decision reflects a further entrenchment of the power disparity between the two "Treaty partners."

\section{Conclusion}

It is clear that there were fundamental contradictions in the perspectives of AgResearch and ERMA on one hand, and those opposing the application on the other, on numerous issues. Those opposing the application provided a range of arguments spanning legal, risk management, economic, scientific, ethical, cultural, and ecological issues that sought to undermine the strongly technoscientific rationale offered by AgResearch. For submitters, for example, the precautionary principle implies that it is morally and legally irresponsible to take risks where the science is uncertain and outcomes could potentially undermine ecological, socio-cultural and economic sustainability. Hence, AgResearch's argument that a double-fenced paddock was sufficient to contain potential GM genes from transgenic cows was viewed very differently by opposing groups. Whilst AgResearch's approach reflects positivist notions of compartmentalised inside/outside space in which a fence can withstand any breakage (through electronic monitoring and controls), by contrast, those opposing the application saw the fence as porous, permeable, subject to leakage and unable to contain either cultural or ecological risks.

The systematic marginalization of issues raised by those opposing the GM application reflects the inadequacy of current ERMA Methodology and practice to provide mechanisms to respond meaningfully to any challenges to the dominant discourse. ERMA's emphasis on "scientific" evidence in evaluating applications tended to override the requirement of the HSNO Act to also engage with values and perspectives peripheral to the pursuit of modern science and technology. Hence, when confronted with a body of scientific arguments against GM science, ERMA exercised its expertise to deem "the alternative science" not credible. Furthermore, the very inclusion of non-quantitative, cultural and ethical concerns in the purview of the HSNO 
Act means that there is some discretionary power available to ERMA, which it has thus far ignored. Indeed, the independent review of ERMA reported the strong perception amongst stakeholders that Agency staff were "pro-approval," and often disrespectful of submitters critical of application, with senior staff referring to submitters as "the enemy" (ERMA,2003: 55).

This article has demonstrated that in making its assessment of which publics and what perspectives were acceptable, ERMA reflected particular values of a "Promethean" technological worldview. Who was deemed credible and what knowledge was legitimate in this decision-making process provides a clear example of what Fischer (1995: 178) calls the "technocratic ideology" that inherently privileges technical expertise. The case study demonstrates ERMA's entrenched ideological belief in the benefits of science, and its view that a specific kind of science was the only possible arbiter of GM risks. The analysis concomitantly demonstrated ERMA's uncritical acceptance of those participants (including the applicant), who presented discourses and rationalities that reflected their own technological priorities, and who supported the application proceeding.

In contrast, those opposing the application who offered a comprehensive range of worldviews, rationalities, and alternative solutions were not seen as legitimate actors in the process. A good example of this was how ERMA effectively delegitimized indigenous Maori knowledge. For instance, ERMA argued that previous ERMA decisions on similar applications had supported the separation of "objective" elements of risk, from "subjective" cultural and spiritual elements. This allowed ERMA to disregard not only the unique, legislatively entrenched partnership Maori have with the Crown, but also discount the arguments offered by Maori as just one unscientific, cultural perspective among many. Although this is partly reflective of a technocentric bias amongst ERMA staff, it is also a reflection of inherently monocultural institutional practice and values that allow for the exclusion of non-mainstream perspectives.

This analysis of public participation in GM decision making in Aotearoa/New Zealand reveals limits placed by institutional structures and practice on any kind of democratic governance of science. Increased avenues for public participation as a means of making decision making more open and responsive to public concerns clearly need to be matched by ensuring that the institutional space for participation-criteria, norms, values, standards, and knowledge (Wagenaar and Cook, 2003) are inclusive of more than technical and scientific discourses. From a deliberative democracy perspective, good decision-making must involve both the public and experts in processes where meaningful deliberation can take place and inform in material ways the decisions that emerge from public institutions. Continued silencing and marginalization of voices of the public and of Maori can lead to a crisis of confidence in democratic practices and processes, which has larger implications for social and ecological sustainability. Good governance of science requires opening up institutional participatory mechanisms to allow for political deliberation, bottom-up decision making, and active citizenship. 
Acknowledgements: We thank Robert V. Bartlett, Debashish Munshi, Andrew Timbrell, Sue Howard and anonymous reviewers for their insights, critiques and helpful feedback. We have also benefited from comments from Patrick Barrett and Rachel Simon-Kumar on an earlier draft of this paper. We thank ERMA New Zealand for facilitating prompt and efficient access to relevant documents. We also gratefully acknowledge on-going support of the Faculty of Arts and Social Sciences at the University of Waikato.

\section{Notes}

${ }^{1}$ The precautionary worldview "approaches the uncertainties associated with any new technology with caution, placing substantial burden of proof on its proponents" (Dryzek, et al., 2009: 4). In the precautionary worldview, "quality of life, freedom, and participation take precedence over quantity of material goods, security, and social order" (ibid.). In contrast, Prometheans have faith in the infinite ingenuity of humans to develop technologies that can override environmental limits. Economic growth and technological innovation "are valued in themselves but also because they are instrumental to further problem solving" (ibid.).

${ }^{2}$ The Treaty of Waitangi, signed in 1840 between over 500 Maori chiefs and the British Crown, set the terms by which Aotearoa/New Zealand became a British colony.

${ }^{3}$ Generic submissions refer to a form for submission made available by anti-GM and environmental networks to the public for signatures. Often submitters added personal comments, included in our analysis.

${ }^{4}$ We have categorized legal and risk management discourses together because concerns about legal issues spill over into concerns about economic, cultural and ecological risks. The HSNO Act defines risk as "the combination of the magnitude of an adverse effect and the probability of its occurrence" (ERMA, 1998: 5). Risk management requires the applicant to assess and report on possible risks of an application and appropriate plans to address them, which ERMA then approves.

${ }^{5}$ The Bioethics Council, established in 2002 within the Ministry for the Environment to advise on the cultural, ethical and spiritual aspects of biotechnology, was disbanded in March 2009 (Radio New Zealand, 2009).

${ }^{6}$ Bleakley made an individual submission, but she is also the spokesperson for GE Free New Zealand.

\section{References}

AgResearch. (2002) GMD 02028 Application to ERMA for approval to develop in containment any genetically modified organism. Hamilton: AgResearch Ruakura.

Alabaster, J. (2002) “'Submission 3593', ERMA Application GMD02028." Wellington: ERMA.

Baber, W. and Bartlett, R.V. (2005) Deliberative Environmental Politics: Democracy and Ecological Rationality. Cambridge, MA: MIT Press.

Bartlett, R.V. (1986) "Ecological Rationality: Reason and Environmental Policy," 
Environmental Ethics 8: 221-239.

Beck, U. (1992) Risk Society: Towards a New Modernity. Sage: London.

Bio-grow (2002) "'Submission 3497' in ERMA Application GMD02028." Wellington: ERMA.

Bleakley, C. (2002) “'Submission 3541' in ERMA Application GMD02028." Wellington: ERMA.

Braun, K. and Schultz, S. (2009) “'...A Certain Amount of Engineering Involved”: Constructing the Public in Participatory Governance Arrangements," Public Understanding of Science Doi: 10.1177/0963662509347814.

Dryzek, J., Goodin, R., Tucker, A., \& Reber, B. (2009) "Promethean Elites Face Precautionary Publics: The Case of GM Foods," Science, Technology \& Human Values. 34(3): 263-88.

Eckersley, R. (1992) Environmentalism and Political Theory: Towards an Ecocentric Approach. Albany, NY: SUNY Press.

ERMA (1998) Annotated Methodology. Wellington: ERMA. http://www.ermanz.govt.nz/resources/publications/pdfs/me089801.pdf.

ERMA (2002a) "Evaluation \& Review Report: Application GMD02028 for Approval to Develop in Containment Genetically Modified Bos Taurus." Wellington: ERMA.

ERMA (2002b) "Environmental Risk Management Authority Decision GMD02028." Wellington: ERMA. http://www.ermanz.govt.nz/newsevents/focus/GMD02028\%20s67A.pdf.

ERMA (2003) A Review of Capability Relating to the Risk Management of New Organisms. Wellington: Ministry for the Environment. http://www.mfe.govt.nz/issues/organisms/other-work/erma-review/ermareview-of-capability-mar03.pdf

Fairclough, N. (1995) Critical Discourse Analysis: The Critical Study of Language. London: Longman.

Ferretti, M.P. (2007) "Why Public Participation in Risk Regulation? The Case of Authorizing GMO Products in the European Union," Science as Culture 16(4): 37795.

Fischer, F. (1995) Evaluating Public Policy. Chicago: Nelson-Hall Publishers.

Friends of the Earth (2002) "'Submission 3836' in ERMA Application GMD02028." Wellington.

Gaventa, J. (2005) "Foreword," in Leach, M., Scoones, I., and Wynne, B. (eds) Science and Citizens: Globalization and the Challenge of Engagement, pp. vii-viii. London: Zed Books.

GE Free NZ (2002) “'Submission 3497' in ERMA application GMD02028." Wellington: ERMA.

Goven, J. (2006) "Processes of Inclusion, Cultures of Calculation, Structures of Power: Scientific Citizenship and the Royal Commission on Genetic Modification," Science, Technology, \& Human Values 31(5): 565-598.

Green Party NZ (2002) "'Submission 3542' in ERMA application GMD02028." Wellington: ERMA. 
Greenpeace (2002) “'Submission 4132' in ERMA application GMD02028.” Wellington: ERMA.

Groundswell (2002) "'Submission 3717' in ERMA application (GMD02028)." Wellington: ERMA.

Hajer, M A. (1995) The Politics of Environmental Discourse: Ecological Modernisation and the Policy Process. Oxford: Clarendon Press.

Hajer, M. (2003) "A Frame in the Fields: Policymaking and the Reinvention of Politics," in Hajer, M. A. and Wagenaar, H. (eds) Deliberative Policy Analysis: Understanding Governance in the Network Society, pp.88-110. Cambridge: Cambridge University Press.

Hajer, M. and Wagenaar, H. (2003) "Introduction" in Hajer, M. and Wagenaar, H. (eds) Deliberative Policy Analysis: Understanding Governance in the Network Society, pp.1-30. Cambridge: Cambridge University Press.

Harrison, P. (2002) “'Submission 3936' in ERMA application GMD02028." Wellington: ERMA.

Henare, D. (1998) "The Law of Difference: Will it Make a Difference?" He Pukenga Korero 4(1): 26-32.

HSNO Act [Hazardous Substances and New Organisms Act] (1996). Wellington.

Irwin, A. (2001) "Constructing the Scientific Citizen: Science and Democracy in the Biosciences," Public Understanding of Science 10: 1-18.

Irwin, A. and Michael, M. (2003) Science, Social Theory and Public Knowledge. Milton Keynes: Open University Press.

Jasanoff, S. (1990) The Fifth Branch: Science Advisers as Policymakers. Cambridge, MA: Harvard University Press.

Jasanoff, S. (2003) "Technologies of Humility: Citizen Participation in Governing Science," Minerva 41 (3): 223-244.

Jasanoff, S. (2005) "'Let Them Eat Cake': GM Foods and the Democratic Imagination," in Leach, M., Scoones, I., and Wynne, B. (eds) Science and Citizens: Globalization and the Challenge of Engagement, pp. 183-98. London: Zed Books.

Kleinman, D., Delborne, J., and Anderson, A. (2009). "Engaging Citizens: The High Cost of Citizen Participation in High Technology," Public Understanding of Science Doi: 10.1177/0963662509347138.

Kurian, P. and Munshi, D. (2006) "Tense Borders: Culture, Identity, and Anxiety in New Zealand's Interweaving Discourses of Immigration and Genetic Modification," Cultural Politics 2(3): 359-379.

Leach, M., Scoones, I, and Wynne, B. (2005). "Introduction: Science Citizenship and Globalization," in Leach, M., Scoones, I., and Wynne, B. (eds) Science and Citizens: Globalization and the Challenge of Engagement, pp. 3-14. London: Zed Books.

Levidow, L. , Carr, S. and Wield, D. (2005) "European Union Regulation of AgriBiotechnology: Precautionary Links Between Science, Expertise, and Policy," Science and Public Policy 32(4): 261-76.

LSN (Life Sciences Network) (2002) “'Submission 4136' in ERMA application GMD02028." Wellington: ERMA. 
March, J. and Olsen, J. (1989) Rediscovering Institutions: The Organizational Basis of Politics. New York: Macmillan.

MAdGE (2002) "'Submission 3591' in ERMA application GMD02028." Wellington: ERMA. Mayer, S., Hill, J., Grove-White, R., and Wynne, B. (1996) "Uncertainty, Precaution and Decision Making: The Release of Genetically Modified Organisms into the Environment," Global Environmental Change Programme Briefing Number 8. Brighton: University of Sussex.

McGregor, N. (2002) "'Submission 3533' in ERMA application GMD02028." Wellington: ERMA.

Mitchell, R. (2002) “'Submission 3523' in ERMA application GMD02028." Wellington: ERMA.

Murphy, P., Munshi, D., Lakhtakia, A., Kurian, P., \& Bartlett, R.V. (forthcoming) "Societal and environmental implications of nanotechnology," in Andrews, D., Scholes, G. \& Wiederrecht, G. (eds) Comprehensive Nanoscience and Technology, Amsterdam: Elsevier.

New Zealand Herald. (2010) Scientists plan human genes for cows, goats. By Eloise Gibson.http://www.nzherald.co.nz/nz/news/article.cfm?c id=1\&objectid=106288 26 [27 February 2010].

Ngai Tahu (2002) “'Submission 3424' in ERMA application GMD02028." Wellington: ERMA.

NKTT (Nga Kaihautu Tikanga Taiao) (2002) "Report on Application GMD02028." http://www.ermanz.govt.nz/BertDocs/GMD02028_GMD02028\%20NKTT\%20repor t.pdf.

Pestre, D. (2008) "Challenges for the Democratic Management of Technoscience: Governance, Participation and the Political Today," Science as Culture 17(2): 10119.

Radio New Zealand (2009). "The Bioethics Council is the next target for Cabinet ministers wanting to save money in the public sector." 8 March 2009. http://www.radionz.co.nz/news/stories/2009/03/06/1245a38e6011

RCGM (Royal Commission on Genetic Modification). (2001) Report of the Royal Commission on Genetic Modification. Wellington.

Roberts, M., Haami, B., Benton, R., Satterfield, T., Finucane, M., Henare, M., \& Henare, M. (2004) "Whakapapa as a Maori Mental Construct: Some Implications for the Debate over Genetic Modification of Organisms," The Contemporary Pacific 16(1): $1-28$.

Rogers-Hayden, T. (2004) Commissioning Genetic Modification: The Marginalisation of Dissent in the Royal Commission on Genetic Modification, unpublished Ph.D. Thesis. Hamilton: University of Waikato.

SAFE (Save Animals from Exploitation) (2002) "'Submission 3464' in ERMA application GMD02028." Wellington: ERMA.

Steyn, B. S. (2002) "'Submission 3771' in ERMA application GMD02028." Wellington: ERMA.

Van Dommelen, A. (1999) Hazard Identification of Agricultural Biotechnology. Ultrecht: 
International Books.

Wagenaar, H. and Cook, S.D. (2003) "Understanding Policy Practices: Action, Dialectic and Deliberation in Policy Analysis," in Hajer, M. and Wagenaar, H. (eds) Deliberative Policy Analysis: Understanding Governance in the Network Society, pp.139-71. Cambridge: Cambridge University Press.

Warren, M. (1992) "Democratic theory and Self-Transformation," American Political Science Review 86(1): 8-23.

Webster, D. C. (2002) “'Submission 3712' in ERMA application GMD02028." Wellington: ERMA.

Wills, P. (2002) "'Submission 3899' in ERMA application (GMD02028." Wellington: ERMA.

Wright, J. and Kurian, P. (2009) "Ecological Modernization vs Sustainable Development: The Case of Genetic Modification Regulation in New Zealand." Sustainable Development. DOI: 10.1002/sd.430.

Wynne, B. (2001) "Creating Public Alienation: Expert Cultures of Risk and Ethics on GMOs," Science as Culture 10(4): 445-81.

\section{Author Biography}

Priya Kurian is Associate Professor of Political Science and Public Policy at the University of Waikato, New Zealand. Her research interests straddle the areas of science and technology studies, environmental policy and politics, and race, gender and postcolonialism. She is the Co-Principal Investigator of a grant from the Royal Society of New Zealand that investigates the prospects for public engagement in the use of new and emerging technologies in New Zealand. Correspondence: Political Science and Public Policy, School of Social Sciences, The University of Waikato, Hamilton 3240, New Zealand. Email: pkurian@waikato.ac.nz

Jeanette Wright is a doctoral candidate in Political Science and Public Policy at the University of Waikato, New Zealand. Her doctoral research focuses on the discourses of sustainable development and ecological modernization in New Zealand, offering a critical evaluation of environmental policy process and practice. Her research utilizes critical discourse analysis in the evaluation of public policy, and she has published an article in the journal Sustainable Development. 